
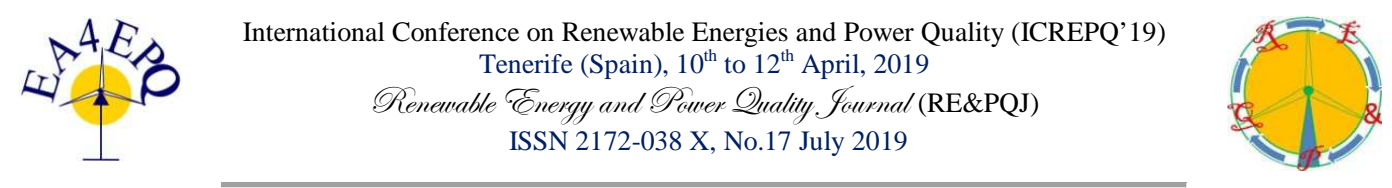

\title{
Red Macroalgae Kappaphycus alvarezii as feedstock for nutraceuticals, pharmaceuticals and fourth generation biofuel production
}

\author{
Oliveira, L.E. ${ }^{1}$, Cedeno, R. F. ${ }^{2}$, Chavez, E. G. ${ }^{2}$, Gelli, V. C. ${ }^{3}$, Masarin, F $^{2}$ \\ ${ }^{1}$ Department of Biodiversity and Conservation \\ A.I., Abepoli Institute \\ Center I - Santa Branca, 12380000 São Paulo (Brazil) \\ Phone/Fax number: +005512991569448, e-mail: levi_ezequiel@yahoo.com.br \\ ${ }^{2}$ Department of Bioprocesses and Biotechnology \\ UNESP, Paulista State University \\ Faculty of Pharmaceutical Science - Araraquara, 14800903 São Paulo (Brazil) \\ Phone/Fax number: +00551633016880, e-mail: fpaz@fcfar.unesp.br,fmasarin@fcfar.unesp.br \\ ${ }^{3}$ Paulista Agricultural Research Agency \\ I.P., Fisheries Institute \\ Secretariat of Agriculture and Supply of the State of São Paulo - São Paulo, 14800903 (Brazil) \\ Phone/Fax number: +00551150670000, e-mail: valeriagelli@uol.com.br
}

\begin{abstract}
Biorefineries intends to utilize algal biomass and their by-products at industrial scale. The macroalgae Kappaphycus alvarezii has high content of carrageenan, which is a polysaccharide hydrocolloid, serving as a raw material for the production of third generation biofuels, food and pharmaceuticals. The aim of this study is to show that besides these products, there is the potential for the production of a fourth generation biofuel. Two strains, brown and red, were selected based on their high growth rates and productivity and were treated with $6 \% \mathrm{KOH}$ for extraction carrageenan extraction. The results of the chemical composition of this residue show that there is considerable amount of fermentable sugar in the carrageenan extraction residue. The glucan conversion was 100 $\%$ for both strains, and the concentrations of glucose from the brown and red strains were 13.7 and $11.5 \mathrm{~g} \mathrm{~L}^{-1}$, respectively. The results highlight the efficiency of generating a key bioproduct from carrageenan residue. This would save the carrageenan that can be used for as a food thickener as it has been used for centuries. Thus, the biorefinery of $K$. alvarezii can be exploited not only to produce carrageenan, but also to generate glucose for future use in biofuel production.
\end{abstract}

\section{Key words}

Biorefinary, residue of carrageenan extraction, fourth generation biofuel

\section{Introduction}

Fossil fuels are the most consumed energy in the world, close to $87 \%$ (oil, coal and natural gas). However, these sources are responsible for global warming by the emission of greenhouse gases (GHG) [1-3].

The first generation of biofuels emerged as an alternative to substitute the fossil fuels, which consists of the use of vegetal biomass for the production of biodiesel and ethanol $[4,5]$. Biofuels emit a very small amount of greenhouse gases and contribute to the mitigation of global warming $[6,7]$.

The production of the plant biomass necessary for the production of biofuels requires large agricultural areas that can have a negative impact because they compete with food sources $[8,9]$. Moreover, the major raw materials for first generation biofuels production are corn, wheat, sugarcane, soybean, rapeseed and sunflowers. However, the issue is that these feedstocks are also used for food production [10].

The second generation biofuel, which is based on waste vegetable biomass, emerged as an alternative for the first generation biofuels. It does not compete directly with food. Moreover, it's production does not require large areas of arable land [11, 12]. However, the pretreatment process required to convert complex carbohydrates into fermentable sugars results in low yield and high cost, implying in a serious technological bottleneck [13, 14]. Biofuels produced from algal biomass are considered third generation, intended to be an alternative for the first and second generations biofuel [15]. The use of algal biomass is also used for the cosmetic, food, nutraceutical, pharmaceutical and biofertilizer industries [16].

The use of red macroalgae Kappaphycus alvarezii is the main worldwide source for bioethanol production, since its high amount of carrageenan that can be converted in fermentable sugar [16]. However, 
macroalgae is also used as a food source, more than five centuries ago, since the populations from the Scandinavian Peninsula started using carrageenan, a polysaccharide of galactose, to produce dairy foods [17-19]. Therefore, that brings up the food versus fuel dilemma again.

The aim of work is to evaluate the chemical composition of the residue generated from carrageenan extraction from Kappaphycus alvarezii, which are monomeric sugar and can be used to produce a third generation bioethanol.

\section{Material and method}

\section{A. Material}

It was used four different Kappaphycus alvarezii seaweed strains that were obtained from the Fisheries Institute, Ubatuba, São Paulo (SP). The used strains were: brown, red, green, and G11. The strains were grown during May and June of 2013. These K. alvarezii strains were grown in the Atlantic Ocean in the experimental field base at Itaguá beach in Ubatuba, SP, Brazil (GPS coordinates $\left.23^{\circ} 27^{\prime} 5,8^{\prime \prime} \mathrm{S} ; 4^{\circ} 02^{\prime} 49,3^{\prime \prime} \mathrm{W}\right)$. The structure used to grow the seaweed strains consisted of a raft anchored in the bay [12].

\section{B. Composition of the samples}

A Soxhlet system was used with hexane-soluble with $99 \%$ (v/v). The samples were air dried, milled, and passed through a $0.84 \mathrm{~mm}$ screen. Approximately, $1 \mathrm{~g}$ of the milled sample was extracted. This procedure was conducted in triplicate.

The milled samples were hydrolyzed with $72 \%$ (w/w) sulfuric acid at $30{ }^{\circ} \mathrm{C}$ for $1 \mathrm{~h}(3 \mathrm{~mL}$ of acid to $300 \mathrm{mg}$ of sample) as described previously. The acid hydrolysate was diluted with $79 \mathrm{~mL}$ of distilled water $(4 \%$ (w/w) sulfuric acid), and the mixture was autoclaved at $121{ }^{\circ} \mathrm{C}$ for $1 \mathrm{~h}$. The residual material was cooled and filtered through a porous glass filter (Scott number 3, Germany). The solids were dried to a constant weight at $105^{\circ} \mathrm{C}$ and were assessed as the insoluble aromatics component. The filtrate was further passed through $0.45 \mu \mathrm{m}$ membranes. The total sugar content in the same solution was determined by the sulfuric acid/phenol method, using sucrose as the calibration standard [18]. The filtrates were evaluated via HPLC/MS analysis (using HPLC Agilent 1200 Series and AB Sciex QTRAP mass spectrometers) to confirm the presence of monomeric sugars.

The detection of the monomeric sugars in the soluble fraction was performed using HPX87P columns (Bio-Rad; Hercules, CA, USA) at $80^{\circ} \mathrm{C}$ by elution with water at a rate of $0.6 \mathrm{~mL} \mathrm{~min}^{-1}$. The mass spectrometer was operated using electrospray ionization (ESI) in positive and negative modes. The ionization source parameters in negative mode were: ion spray: $-4500 \mathrm{~V}$; curtain gas: $15 \mathrm{psi}$; temperature: $650{ }^{\circ} \mathrm{C}$; gas 1:50 psi; gas 2:50 psi; and heater interface: on. The ionization source parameters in the positive mode were as follows: ion spray: $5500 \mathrm{~V}$; curtain gas: 15 psi; temperature: $650{ }^{\circ} \mathrm{C}$; gas 1:50 psi; gas 2:50 psi; heater interface: on. The standards were diluted to $1 \mathrm{mg} \mathrm{L}^{-1}$ in water with $0.1 \%$ acetic acid, and the optimization was performed by direct infusion into the automatic flow $\left(10 \mathrm{~L} \mathrm{~min}^{-1}\right)$ using a syringe [12].

The concentrations of monomeric sugars in the soluble fraction were determined by HPLC (HPX87P column; Bio-Rad, Hercules, CA, USA) at $80^{\circ} \mathrm{C}$ using water as the eluent at a flow rate of $0.6 \mathrm{~mL} \mathrm{~min}^{-1}$. Sugars were detected using a temperature-controlled refractive index detector at $45{ }^{\circ} \mathrm{C}$. Glucose, xylose, mannose, and galactose were used as external calibration standards. Corrections were performed by considering the anhydrogalactose-degradation reactions that took place during acid hydrolysis. Under the present acid hydrolysis conditions, all the anhydrogalactose present in the sample is degraded. Thus, the anhydrogalactose content in the carrageenans and agars was calculated using the galactose to anhydrogalactose ratio of $1: 1.27$. The factor used to convert the sugar monomers to anhydromonomers was 0.9 for glucose and galactose. This procedure was conducted in triplicate. Glucose was reported as glucan and galactose and anhydrogalactose as galactan after correction by the hydrolysis factor. The concentration of hydroxymethylfurfural and furfural in the soluble fractions was determined using an HPLC instrument equipped with a $250 \mathrm{~mm}$ long column with an outer diameter of $4 \mathrm{~mm}$ (Hypersil; Thermo-Scientific) using acetonitrile:water (1:8) containing $1 \%(\mathrm{v} / \mathrm{v})$ acetic acid as an eluent at a flow rate of $0.8 \mathrm{~mL} \mathrm{~min}^{-1}$. Hydroxymethylfurfural and furfural were detected at $276 \mathrm{~nm}$.

\section{Results and discussion}

The productivity and growth rate of different strains of $K$. alvarezii used in this study were evaluated based on an experimental field test in Ubatuba, São Paulo (SP), Brazil. The productivity ranged from 15.9 to $46.0 \mathrm{~g}$ $\mathrm{m}^{2}$ day $^{-1}$, and the growth rate ranged from 3.8 to $6.2 \%$ day $^{-1}$ (Figure 1).

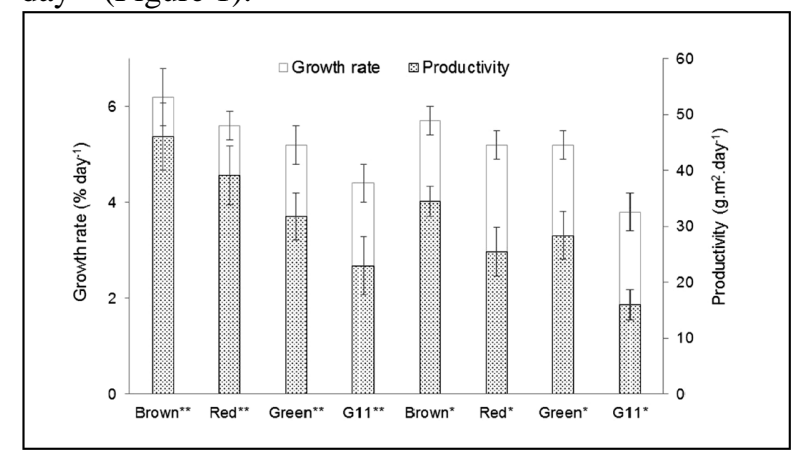

Fig. 1. Growth rate and productivity of different strains from K. alvarezii. Contents present in percentage day-1 and $\mathrm{g} \mathrm{m}^{2} \mathrm{day}^{-1}$, respectively. Asterisks Cultivation for June 2013. Two asterisks cultivation for May de 2013 [12].

The G11 strain showed the lowest productivity and growth rate of the evaluated strains. The brown and red strains grown in May 2013 showed higher productivity than the brown and red strains grown in June 2013. The average data presented were similar to those reported in 
the literature and the values were characteristic of $K$. alvarezii crops in the Ubatuba-SP region [12].

In addition to the total carbohydrates, the profile of monomeric sugars in the $K$. alvarezii strains was also analyzed (Figure 2). HPLC-MS analysis indicated the presence of anhydrogalactose, galactose, glucose, mannose, and xylose. In addition, rhamnose was detected in trace amounts due to the small portion of pectin in $K$. alvarezii biomass, derived from galacturonic acid. The percentage of galactose, anhydrogalactose, glucose, mannose, and xylose in the strains ranged from 13.8-14.5, $17.3-21.6,11.3-13.0,0.9-1.6$, and $0.5-0.8 \%$, respectively (Figure 2). Thus, the major polysaccharides found in $K$. alvarezii were galactans (from galactose and anhydrogalactose), followed by glucans (from glucose).

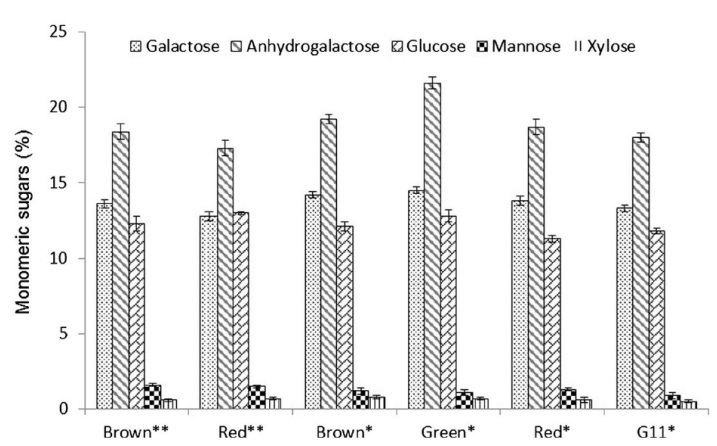

Fig. 2. Sugar composition monomeric different strains of $K$. alvarezii. Contents present in percentage $(\mathrm{g} / 100 \mathrm{~g}$ of original material in dry basis). Asterisks Cultivation for June 2013. Two asterisks cultivation for May 2013 [12].

The carbohydrate constituted the main component for all studied strains. The average total carbohydrate content determined herein was $53.4 \%$, whereas that documented in the literature for the same species is around $63 \%$ [13]. The reported total carbohydrate content of the species Gelidium amansii (red macroalgae) is around 78 $\%$. The highest total carbohydrate values (54.6 and $55.8 \%$, respectively) were obtained for the brown and green strains, both grown in June 2013. Ash accounted for the second major component of the samples. The brown strain grown in May 2013 had the lowest ash content (14.6\%) and the G11 strain grown in June 2013 had the highest ash content $(17.2 \%)$. The ash contents of the other strains of the same species did not differ significantly. On average, the observed ash contents were similar to that reported in the literature for the same species [14].

The enzymatic hydrolysis was performed using commercial enzyme preparations (Cellic CTec II, Novozymes, Denmark) at a dosage of 10 FPU per gram of sample (dry weight basis), corresponding to $200 \mathrm{IU}$ of $\beta$ glucosidase. The total cellulases and $\beta$-glucosidase activity determined using the Celic CTec II extract were 92 FPU $\mathrm{mL}^{-1}$ and $1800 \mathrm{UI} \mathrm{mL}^{-1}$, respectively. Each hydrolysis experiment was conducted in $50 \mathrm{~mL}$ Falcon tubes containing $200 \mathrm{mg}$ of milled sample (dry weight basis) and $10 \mathrm{~mL}$ of $50 \mathrm{mM}$ sodium-acetate buffer $(\mathrm{pH} 4.8)$ in addition to the enzyme solution. The flasks were incubated at $45^{\circ} \mathrm{C}$ with rotary agitation at $120 \mathrm{rpm}$. The reaction was stopped at defined periods from 4 to $72 \mathrm{~h}$ by heating the flask to $100{ }^{\circ} \mathrm{C}$ for $5 \mathrm{~min}$, followed by centrifugation of the material at $7000 \times \mathrm{g}$ for $10 \mathrm{~min}$.

The soluble fractions were assayed for glucose using HPLC with an HPX87P column (Bio-Rad) at $45^{\circ} \mathrm{C}$ using water as an eluent at an elution rate of $0.6 \mathrm{~mL}$ min-1. The sugars were detected using a temperaturecontrolled infrared detector set at $45{ }^{\circ} \mathrm{C}$. The glucan conversion level reported herein refers to the conversion of the polysaccharides to their monomers. The values (mean \pm SD) for the hydrolysis of the samples were estimated from triplicate.

The semi-refined carrageenan and its residue were successfully obtained by extraction the soxhlet method. The enzymatic hydrolysis shows that the residue yielded high concentrations of glucose, with complete conversion of glucan. Therefore, these results highlight the viability of this byproduct of carrageenan extraction as a monomeric sugar for the eventual production of bioethanol. Since this residue is considered waste and not a food source, this method would be a fourth generation model for the production of biofuels. In summary, we have demonstrated a novel aspect to the biorefining Kappaphycus alvarezii for developing not only carrageenan, but also the bioproduct glucose (Figure 3 ).

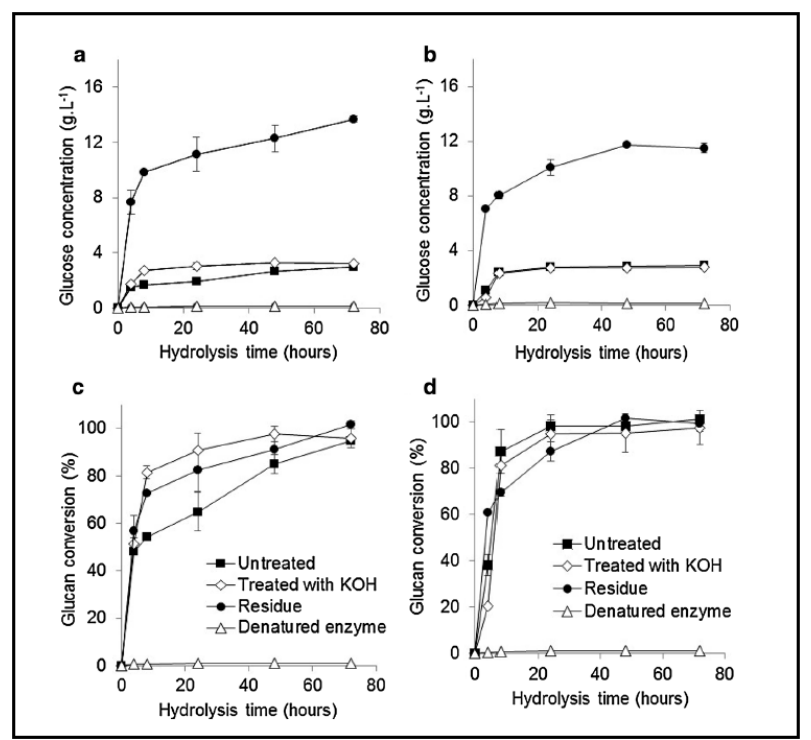

Fig. 3. Glucose concentration and glucan conversion over time for enzymatic hydrolysis from K. alvarezii fractions cultivation for May 2013. a Glucose concentration of brown strain. b Glucose concentration of red strain. c Glucan conversion of brown strain. d Glucan conversion of red strain. (square filled) untreated material, (lozenge open) treated with $\mathrm{KOH} 6 \%$ (w/v) material, (ball filled) residue and (triangle open) residue plus enzyme denature. All symbols apply to the graphs a-d. All reported data are the average values followed by their standard deviations [12]. 


\section{Conclusion}

The evaluation of the four different $K$. alvarezii strains shows different rates of productivity and growth. Nevertheless, all the studied strains had comparable total carbohydrate levels. The main carbohydrate polymers detected were galactan and glucan. Other important components were ash (mainly comprised calcium, potassium, and sodium) and sulphate groups. Semi-refined carrageenan and its residue were obtained from the two selected strains. The enzymatic hydrolysis of the residue yielded high concentrations of glucose, with complete conversion of glucan. These results demonstrate the viability of this byproduct of carrageenan extraction as a monomeric sugar for the eventual production of the fourth generation bioethanol.

Since carrageenan is widely used by the food industry, the use of the residue obtained by carrageenan extraction shows an important alternative for the food verses biofuel dilemma and opens a new frontier for a new generation of biofuels using the biorefinary concept on the algal biomass to produce several products including food, nutraceuticals and pharmaceuticals.

\section{Acknowledgement}

Thanks for the sample donation of the Fisheries Institute of Secretariat of Agriculture and Supply of the State of São Paulo - São Paulo (Brazil).

\section{References}

[1] Bilanovic, D.; Andargatchew, A.; Kroeger, T.; Shelef, G., Freshwater and marine microalgae sequestering of $\mathrm{CO} 2$ at different $\mathrm{C}$ and $\mathrm{N}$ concentrations, v. 50:262-7, 2009.

[2] Cardone, M.; Mazzocini, M.; Menini, S.; Rocco, V.; Senatore, A., Seggiani, M.; Vitolo, S. Brassica carinata as an alternative oil crop for the production of biodiesel in Italy: agronomic evaluation, fuel production by transesterification and characterization. Biomass Bioenergy, v. 25, p. 623-636, 2003.

[3] Fargione, J., Hill, J., Tilman, D., Polasky, S., Hawthorne, P., Land clearing and the biofuel carbon debt. Science, v. 319 p. 1235-38, 2008 .

[4] Searchinger T, Heimlich R, Houghton RA, et al. Use of U.S. croplands for biofuels increases greenhouse gases through emissions from land-use change. Science. v. 319, p. 1238-40, 2008.

[5] Borowitzka, M.A. Algal biotechnology products and processes - matching science and economics. J Applied Phycology, v. 4, p. 267-279, 1992.

[6] Lim, S.; Teong, L.K. Recent trends, opportunities and challenges of biodiesel in Malaysia: an overview. Renew Sustain Energy Rev, v. 14, p. 938-954, 2010.

[7] Oliveira, L.E.; Eduardo, M.P.; Castro, H.F. ; Giordani, D.S.; Silva, M.L.C., Kinetic and thermodynamic parameters of volatilization of biodiesel from babassu, palm oil and mineral diesel by thermogravimetric analysis (TG). Journal of Thermal Analysis and Calorimetry, v. 108, p. 1, 2012.

[8] Zodape, S.T., Mukherjee, S., Reddy, M.P., Chaudhary, D.R., Effect of Kappaphycus alvarezii (Doty) extract on grain quality, yield and some yield components of wheat (Triticum aestivum L.), Int J Plant Prod, v. 3, p. 1735-8043.

[9] Park, J.H., Hong, J.Y., Jang, H.C., Oh, S.G., Kim S.H., Yoon, J.J., Kim, Y.J., Use of Gelidium amansii as a promising resource for bioethanol: a practical approach for continuous dilute-acid hydrolysis and fermentation. Bioresour Technol, v. 108:83-8, 2012.

[10] Ajanovic, A., Biofuels versus food production: Does biofuels production increase food prices? Energy, v. 36, p. 2070-76, 2011.

[11] Oliveira, L.E., Barboza, J.C.S., Da Silva, M.L.C.P., Production of ethylic biodiesel from Tilápia visceral oil, Renewable Energy and Power Quality Journal, v. 11, p. 683-86, 2013.

[12] Masarin, F., Cedeno, F.R.P., Chavez, E.G.S., Oliveira, L.E., Gelli, V.C., Monti, R., Chemical analysis and biorefinery of red algae Kappaphycus alvarezii for efficient production of glucose from residue of carrageenan extraction process, Biotechnol Biofuels v. 9, p. 1-12, 2016.

[13] Kim, S., Dale, B.E., Global potential bioethanol production from wasted crops and crop residues. Biomass Bioenergy, v. 26, p. 361-75, 2004.

[14] Adams, J.M., Gallagher, J.A., Donnison, I.S., Fermentation study on Saccharina latissima for bioethanol production considering variable pre-treatments, J Appl Phycol, v. 21:569$74,2009$.

[15] Chisti, Y., Biodiesel from microalgae, Biotechnol Adv. v. 25, p. 294-306, 2007.

[16] Hayashi, L., Reis, P.R., Cultivation of the red algae Kappaphycus alvarezii in Brazil and its pharmacological potential. Braz J Pharmacogn, p. 22:748, 2012.

[17] Souza, M.O., Garrett, R., Pereira, M.M., Miranda, L.S.M, Use of Kappaphycus alvarezii Biomass for the Production of Carbohydrate Isopropylidene-Ketal-Based, Biocrude, Energy Fuels, v. 31, p. 9422-28, 2017.

[18] Yoon, J.J., Kim, Y.J., Kim, S.H., Ryu, H.J., Choi, J.Y., Kim G.S., Shin, M.K., Production of polysaccharides and corresponding sugars from red seaweed, Adv Mater, v. 93, p. 463-6, 2010.

[19] Hayashi, L., Oliveira, E.C., Bleicher-Lhonneur, G., Boulenguer, P., Pereira, R.T.L., Seckendorff, R.V., Shimoda V.T., Leflamand, A., Vallée, P., Critchley, A.T., The effects of selected cultivation conditions on the carrageenan characteristics of Kappaphycus alvarezii (Rhodophyta, Solieriaceae) in Ubatuba Bay, São Paulo, Brazil. J Appl Phycol. v. 19, p. $505-11,2007$. 